\title{
DAMPAK PEMBELAJARAN REFLEKTIF BAGI CALON GURU AGAMA KATOLIK TERHADAP PANGGILAN KEGURUAN
}

\author{
Albert I Ketut Deni Wijaya, Antonius Virdei Eresto Gaudiawan \\ STKIP Widya Yuwana \\ albert.deni@yahoo.com \\ antoniuseresto@yahoo.com
}

\begin{abstract}
Many research has been done on reflective learning. Various studies have shown that reflective learning has a positive impact on students in capturing learning material. Seeing the results of the study, researchers wanted to see how reflective learning can help prospective Catholic teacher teachers increasingly become teachers. Becoming a true teacher is a noble calling, even more so becoming a religious teacher. Because being a religious teacher is not enough to just convey material or transfer knowledge but it must also be accompanied by example in everyday attitudes and actions. Based on the situation above, the researcher formulated 2 problems. First, what is the reflective learning model given to prospective Catholic teachers? Second, how does reflective learning impact Catholic teacher candidates on teacher vocations? This research uses descriptive qualitative research. Data collection techniques were carried out using the FGD (Focus Group Discussion) method. Analysis of qualitative research is inductive. Based on the results of the study, it was found that reflective learning had a great impact on the vocational vocations of Prospective Catholic Religious Teachers. Thus, reflective learning models really need to be developed in the learning process for prospective religious teachers.
\end{abstract}

Keywords: Reflective Learning; Catholic Teacher candidate; Teacher Vocation. 


\section{PENDAHULUAN}

Penelitian tentang pembelajaran reflektif telah banyak dilakukan. Mulai dari penelitian Stefania Dwiana Putri (2016) bersama rekan-rekannya, Fredi Ganda Putra (2016), Albertus Hartana (2016) bersama rekan-rekan, maupun Marnita (2017). Penelitian mereka semua menunjukkan bahwa pembelajaran reflektif berdampak positif bagi para peserta didik dalam menangkap materi pembelajaran.

Melihat hasil penelitian tersebut, peneliti ingin melihat bagaimana pembelajaran reflektif dapat membantu para mahasiswa calon guru agama Katolik semakin terpanggil menjadi guru. Sebab dewasa ini berbicara tentang guru berarti berbicara tentang profesionalisme kerja. Ketika berbicara profesionalisme tentu saja tidak lepas dari uang. Sebab seorang yang bekerja secara profesional pasti akan menuntut pendapatan yang sesuai (Wahyuni, 2014).

Menjadi guru merupakan sebuah profesi. Profesi sendiri harus dipahami sebagai suatu pekerjaan dimana membutuhkan keahlian khusus dan tidak dapat dilakukan oleh sembarang orang. Dalam hal ini menjadi seorang guru berarti membutuhkan keahlian yang khusus, maka disebut pula sebagai profesi. Mengingat guru adalah sebuah profesi yang membutuhkan keahlian khusus maka menjadi guru juga dituntut profesionalisme kerja. Guru yang profesional dapat dipandang dari 3 dimensi, yaitu: ahli di bidangnya, memiliki tanggung jawab dan memiliki rasa kesejawatan (Wahyuni, 2014).

Selain sebuah profesi, menjadi seorang guru juga merupakan sebuah panggilan yang suci. Bahkan menjadi guru adalah panggilan Ilahi (Wahyuni, 2014). Pandangan tersebut muncul tentu karena menjadi guru berarti harus siap melayani para peserta didik dengan sepenuh hati. Sikap ini tentu tidak lepas dari sikap Tuhan sendiri yang senantiasa mengasihi manusia dengan sepenuh hati.

Menjadi seorang guru yang melayani dengan sepenuh hati tentu tidaklah mudah. Ada berbagai tantangan yang harus siap dihadapi dan diatasi. Pertama, menjadi seorang guru harus bisa melayani semua lapisan masyarakat. Kedua, menjadi seorang guru tidak hanya mengajar dengan kata-kata namun juga sikap, tingkah laku dan perbuatan. Ketiga, lebih mengutamakan siswa dari pada materi.

Dewasa ini pandangan guru dalam dunia pendidikan tidak hanya mendidik

dan mengajar saja. Guru harus berperan sebagai pengajar, pembimbing, pemimpin, ilmuwan, pribadi, penghubung, pembaharu dan pembangun (Wahyuni, 2014). Dengan demikian, cara pandang menjadi guru itu untuk mencari uang tentu cara pandang yang keliru. Menjadi guru sejatinya adalah panggilan yang mulia (Wahyuni, 2014), terlebih lagi menjadi guru agama. Sebab menjadi guru agama tidak cukup hanya menyampaikan materi atau transfer ilmu namun juga harus disertai keteladanan dalam sikap dan perbuatan nyata sehari-hari. Maka pembelajaran bagi para calon guru agama Katolik yang tidak disertai kegiatan 
refleksi dirasa dapat merusak cara pandang profesi guru sebagai sebuah panggilan. Sehubungan dengan itu, maka pembelajaran reflektif dirasa perlu diberikan juga bagi para calon guru khususnya calon guru agama Katolik. Melalui pembelajaran reflektif diharapkan para calon guru agama ini dapat semakin melihat, menyadari dan menghayati bahwa menjadi guru adalah sebuah panggilan yang mulia.

Pembelajaran reflektif merupakan sebuah proses pembelajaran dimana antara peserta didik dan materi pelajaran saling berinteraksi dengan dibantu oleh pendidik. Pembelajaran ini menjadikan peserta didik sebagai pusat pembelajaran guna mengantar mereka pada kesadaran akan pengetahuan dan nilai dengan penuh tanggung jawab. Pembelajaran reflektif akan membuat para peserta didik tidak hanya memiliki pengetahuan yang baik namun juga mampu mengembangkan cara berpikir, bertindak, hati nurani, serta kehendak untuk berbela rasa terhadap orang lain (Suparno, 2015:15).

Pembelajaran reflektif dapat dilakukan dengan 5 langkah. Langkah pertama melihat konteks, langkah kedua pengalaman, langkah ketiga refleksi, langkah keempat aksi dan langkah kelima evaluasi.

a. Pengenalan Konteks. Dalam proses pengenalan konteks, pengalaman manusiawi menjadi dasar dalam pembelajaran reflektif. Hal ini berarti, pembelajaran reflektif terjadi dalam suatu konteks tertentu. Suatu konteks yang berangkat dari kehidupan nyata yang dialami oleh peserta didik (Saptono, 2012:79).

b. Penyajian Pengalaman. Saptono (2012:79-80) mengatakan: "Pengalaman yang dimaksud di sini adalah setiap kegiatan yang bercirikan adanya pemahaman kognitif dari bahan yang disimak serta pelibatan dimensi afektif siswa. Di sini, pengalaman bisa dibedakan menjadi dua, yaitu pengalaman langsung dan tidak langsung. Pengalaman langsung adalah pengalaman real yang secara langsung dihadapi siswa. Pengalaman tak langsung adalah pengalaman real orang lain atau pengalaman rekaan”.

c. Refleksi. Refleksi sendiri merupakan suatu upaya untuk menangkap materi dengan penuh perhatian. Materi yang diberikan dapat berupa bahan studi tertentu, ide, usul atau bahkan reaksi spontan. Lewat refleksi peserta didik belajar menggali makna dan konsekuensi atas sebuah pengalaman. Dalam proses refleksi, tugas pendidik adalah merumuskan pertanyaan refleksi, dan ini bukanlah tugas yang mudah (Saptono, 2012:80).

d. Aksi. Subagya (2010:80) menyatakan bahwa aksi merupakan pertumbuhan batin seseorang berdasarkan pengalaman yang telah direfleksikan dan juga manifestasi lahiriahnya. Aksi meliputi dua hal : a) pilihan batin, yaitu pilihan yang didasari oleh keyakinan bahwa keputusan yang diambil adalah benar dan dapat membawa pada pribadi yang lebih baik, b) pilihan lahir, yaitu pilihan setelah niat-niat yang dirumuskan diolah dalam pikiran, peserta didik 
akan terdorong untuk berbuat secara konsisten sesuai dengan prioritas yang telah dibuatnya. Jika menemukan makna yang positif, maka perbuatan akan menjadi kebiasaan yang menguntungkan.

e. Evaluasi. Evaluasi merupakan kegiatan yang dilakukan untuk meninjau kemajuan yang dicapai dalam proses pembelajaran dalam bentuk penilaian. Fokus penilaian tidak hanya pada akademiknya, tetapi juga memperhatikan pertumbuhan dan perkembangan peserta didik secara menyeluruh sebagai makhluk pribadi maupun sosial (Wahana, 2018: 23). Menurut Subagya (2010:80) hendaknya evaluasi dilakukan seefektif mungkin, dilakukan secara menyeluruh dan rutin. Evaluasi sendiri hendaknya menjadi sarana guna meningkatkan perkembangan perilaku dan kebiasaan peserta didik.

Berdasarkan situasi di atas, peneliti merumuskan 2 permasalahan. Pertama, bagaimana model pembelajaran reflektif yang diberikan kepada para calon guru agama Katolik? Kedua, bagaimana dampak pembelajaran reflektif bagi calon guru agama Katolik terhadap panggilan keguruan? Berdasarkan permasalahan tersebut, maka penelitian ini bertujuan untuk (1) Mengetahui model pembelajaran reflektif yang dialami para calon guru agama Katolik; (2) Mengetahui dampak pembelajaran reflektif bagi calon guru agama Katolik terhadap panggilan keguruan.

Penelitian ini menggunakan metode kualitatif deskriptif. Jenis penelitian ini diharapkan dapat menangkap berbagai informasi kualitatif dengan deskripsi teliti dan penuh nuansa, yang lebih dari sekedar pernyataan jumlah ataupun frekuensi dalam bentuk angka. Teknik pengumpulan data dilakukan dengan metode FGD (Focus Group Discussion). Melalui metode ini peneliti akan dapat memperoleh informasi lebih dalam dan lengkap. Untuk itu, proses wawancara dilakukan dengan pertanyaan yang bersifat terbuka, dan mengarah pada kedalaman informasi serta dilakukan dengan cara yang tidak terstruktur/informal.

Tempat penelitian ini di STKIP Widya Yuwana Madiun, program Studi Ilmu Pendidikan Teologi (Pendidikan Guru Agama Katolik). Penelitian dilaksanakan di prodi tersebut dengan pemikiran bahwa prodi tersebut secara khusus mendidik para calon Guru Agama Katolik (sasaran utama penelitian).

Analisis penelitian kualitatif bersifat induktif. Bahwa semua simpulan dibentuk dari semua informasi yang diperoleh dari lapangan. Proses analisis ini dilakukan bersamaan sejak awal dengan proses pengumpulan data, dengan melakukan berbagai teknik refleksi bagi pendalaman dan pemantapan data. Setiap data yang diperoleh akan dikomparasikan untuk melihat keterkaitan sesuai dengan tujuan penelitian. 


\section{PEMBAHASAN}

Berdasarkan hasil penelitian tentang pembelajaran reflektif, peneliti mengelompokkan hasil penelitiannya ke dalam 4 bagian. Keempat bagian tersebut meliputi: pemahaman responden tentang model pembelajaran reflektif, keunggulan dan kelemahan pembelajaran reflektif, dampak pembelajaran reflektif bagi perkembangan calon guru dan pengaruh pembelajaran reflektif dalam memotivasi sebagai calon guru.

\subsection{Pemahaman Tentang Model Pembelajaran Reflektif}

Hasil penelitian kepada para responden menunjukkan terdapat 3 jenis jawaban yang paling dominan terkait pemahaman tentang pembelajaran reflektif. Ketiga jenis jawaban tersebut yaitu: pertama, pembelajaran reflektif sebagai model pembelajaran yang kontekstual; kedua, pembelajaran refleksi sebagai model pembelajaran dengan memaknai proses; ketiga, model pembelajaran yang biasa mereka alami dalam perkuliahan namun kurang dipahami.

Grafik 1: Pemahaman Model Pembelajaran Reflektif

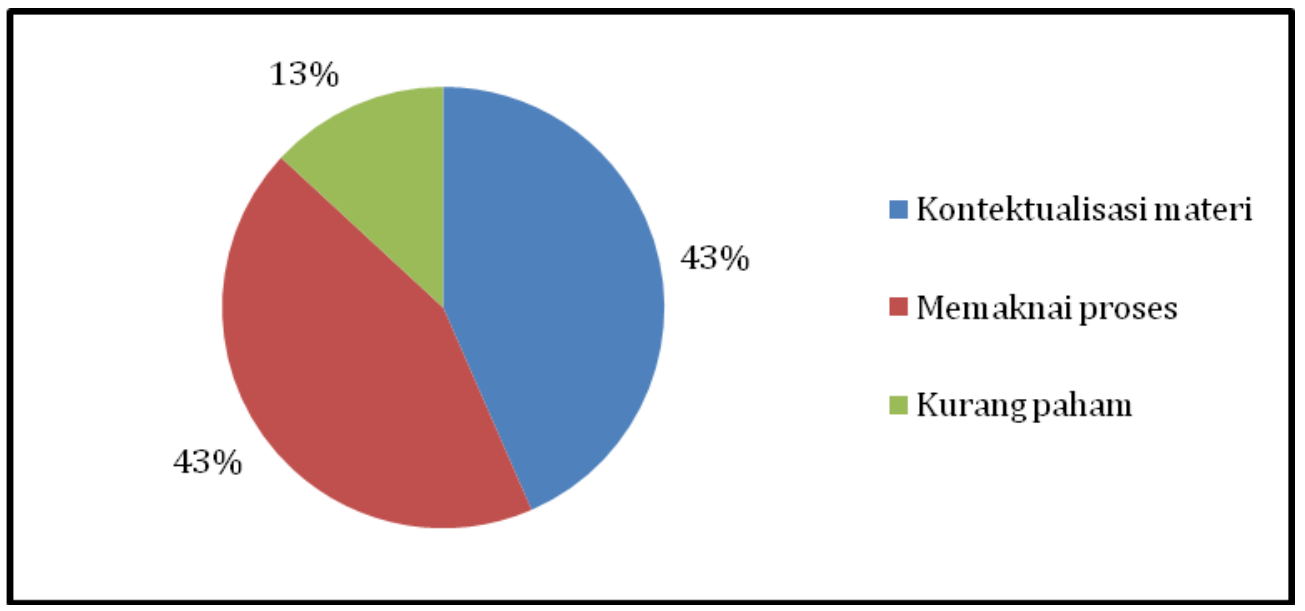

Pertama, pembelajaran reflektif sebagai model pembelajaran yang kontekstual. Maksud dari jawaban ini adalah pembelajaran reflektif membantu para responden untuk mampu mengaitkan materi yang mereka alami dengan kebutuhan dan tantangan pada dunia nyata. Dengan demikian pembelajaran yang mereka ikuti menjadi lebih relevan karena dapat dilihat keterkaitannya dengan kehidupan nyata.

Kedua, pembelajaran reflektif sebagai model pembelajaran dengan memaknai proses. Maksud dari jawaban ini adalah pembelajaran reflektif membantu para responden untuk mampu memaknai seluruh materi yang mereka peroleh tidak hanya sebatas pengetahuan saja tetapi juga menjadikan pengetahuan itu sebagai bagian dari pengalaman hidup mereka masing-masing. Hal ini berarti 
pembelajaran reflektif membantu peserta untuk semakin menginternalisasi materi pembelajaran. Lewat pembelajaran reflektif, peserta merasa bahwa materi pembelajaran yang diberikan sesuai dengan pengalaman hidup mereka dan ini tentu akan berdampak baik bagi pemahaman, penghayatan dan aplikasi ilmu pengetahuan.

Ketiga, pembelajaran reflektif sebagai model pembelajaran yang biasa mereka lami namun kurang dipahami. Maksud dari jawaban ini adalah para responden menyadari bahwa mereka sering mengikuti pembelajaran yang disertai dengan proses reflektif, namun mereka kurang begitu paham akan apa maksud dari pembelajaran reflektif itu sendiri. Hal ini juga berarti bahwa dari sisi pengalaman responden pernah mengalami model pembelajaran reflektif, namun dari sisi pemahaman tentang apa itu pembelajaran reflektif, responden kurang begitu memahami.

Tentang pembelajaran reflektif suparno (2015:15) mengungkapkan bahwa dalam proses pembelajaran reflektif antara peserta didik dan materi pelajaran saling berinteraksi dengan dibantu oleh pendidik. Pembelajaran ini menjadikan peserta didik sebagai pusat pembelajaran guna menghantar mereka pada kesadaran akan pengetahuan dan nilai dengan penuh tanggung jawab. Pembelajaran reflektif akan membuat para peserta didik tidak hanya memiliki pengetahuan yang baik namun juga mampu mengembangkan cara berpikir, bertindak, hati nurani, serta kehendak untuk berbela rasa terhadap orang lain.Berdasarkan ketiga jenis jawaban tersebut dapat disimpulkan bahwa para responden meskipun secara teori kurang mampu menjelaskan dengan baik, namun pada umumnya mereka memiliki pemahaman yang baik tentang pembelajaran reflektif.

\subsection{Keunggulan dan Kelemahan Pembelajaran Reflektif}

Berdasarkan hasil penelitian diperoleh data terkait keunggulan dan kelemahan pembelajaran reflektif. Terkait keunggulan pembelajaran reflektif, diketahui terdapat 8 keunggulan menurut para responden, yaitu: pembelajaran reflektif membantu untuk memahami materi, kontekstualisasi materi, memaknai pengalaman, memurnikan motivasi, mengevaluasi materi, memperbaiki diri, pedoman hidup dan berpikir kritis. 
Grafik 2: Keunggulan Pembelajaran Reflektif

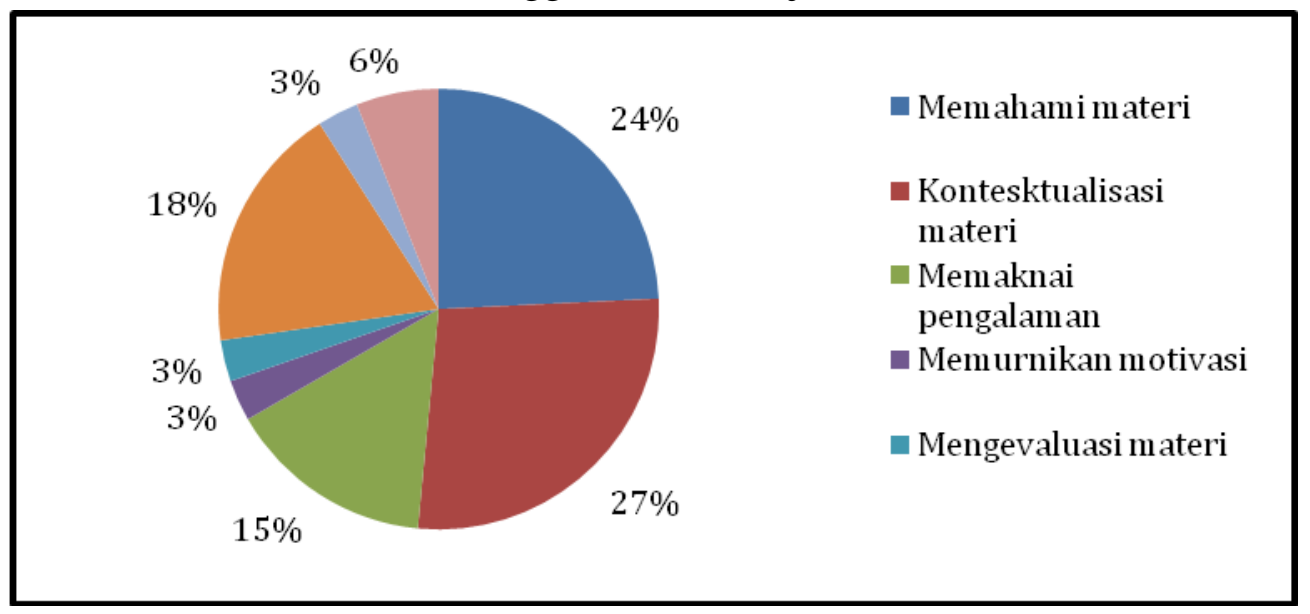

Meskipun terdapat 8 keunggulan dari pembelajaran reflektif, namun jika dicermati ternyata hanya 4 jenis jawaban yang paling dominan muncul. 4 jawaban yang paling sering muncul yaitu: pertama, pembelajaran reflektif membantu peserta untuk mampu mengkontektualisasikan materi yang mereka peroleh dengan pengalaman hidup sehari-hari (27\%). Kedua, pembelajaran reflektif membuat para responden semakin mampu memahami materi yang diajarkan (24\%). Ketiga, pembelajaran reflektif membantu peserta untuk memperbaiki diri (18\%). Keempat, pembelajaran reflektif membantu para responden dalam memaknai pengalaman hidup.

Hasil penelitian juga memperoleh data tentang kelemahan pembelajaran reflektif. Terdapat 5 kelemahan dari pembelajaran reflektif menurut para responden, yaitu: pembelajaran reflektif akan kurang berdampak jika dijadikan sebagai penilaian, peserta kurang mampu berefleksi, peserta demi nilai akan berbohong, membutuhkan waktu yang lama dan dipengaruhi oleh suasana hati.

\section{Grafik 3: Kelemahan Pembelajaran Reflektif}

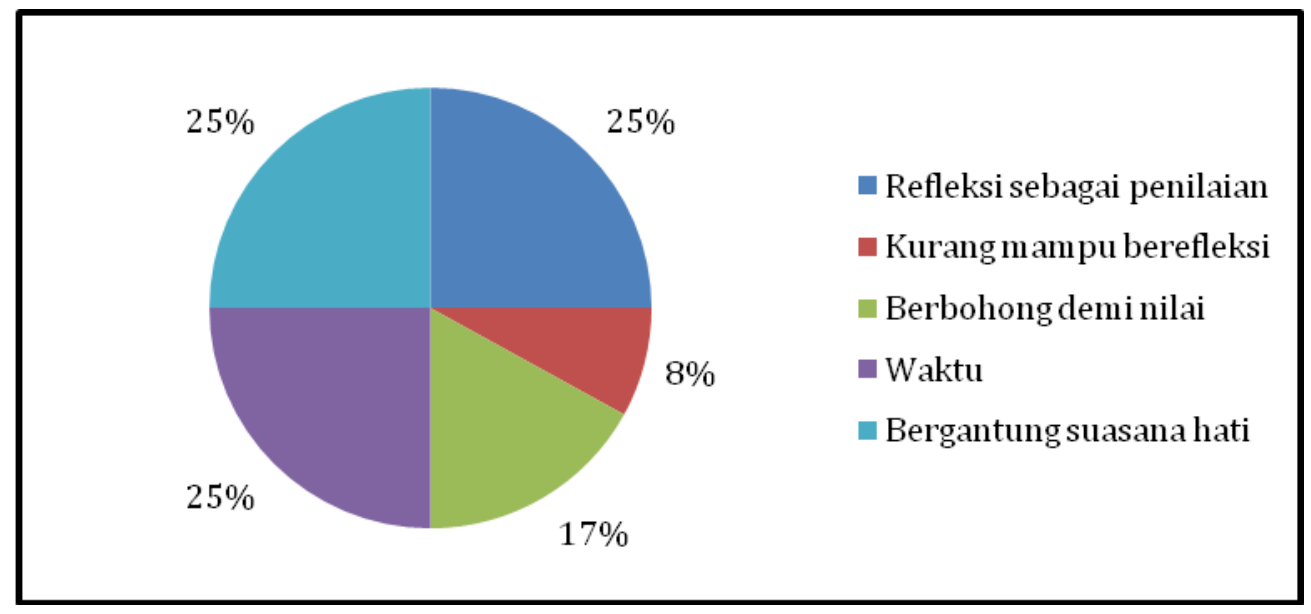


Berdasarkan jawaban terkait kelemahan dari pembelajaran reflektif, kelemahan yang paling mencolok secara garis besar adalah tentang penggunaan pembelajaran reflektif sebagai salah satu item penilaian. Menurut responden, jika pembelajaran reflektif digunakan sebagai penilaian maka dapat memunculkan kesan mengejar nilai. Realita ini akan membuat peserta didik lebih mementingkan nilai yang baik dari pada kejujuran atas proses, dinamika dan evaluasi yang dilakukan. Dengan demikian para pendidik perlu lebih bijaksana dalam menggunakan pembelajaran reflektif dalam proses pembelajaran, dan hendaknya menjadikan refleksi sebagai sarana untuk mendapatkan masukan/mengevaluasi perkembangan kepribadian peserta didik, bukan untuk penilaian.

Dengan demikian dapat disimpulkan bahwa pembelajaran reflektif memiliki kelebihan dan kelemahan. Kelebihan dari pembelajaran reflektif hendaknya dapat dilihat sebagai peluang bagi para pendidik guna meningkatkan keberhasilan proses pembelajaran yang dilakukan. Sedangkan kelemahan yang muncul hendaknya dijadikan masukan dan lebih berhati-hati terkait penggunaan pembelajaran reflektif dalam proses pembelajaran.

\subsection{Dampak Pembelajaran Reflektif bagi Perkembangan Kepribadian Calon Guru}

Hasil penelitian kepada para responden menunjukkan terdapat 5 jenis jawaban dari para responden. Kelima jenis jawaban tersebut yaitu, pertama, bahwa pembelajaran reflektif membantu dalam mengetahui tugas sebagai guru; kedua, pembelajaran reflektif membantu dalam menyiapkan diri sebagai guru; ketiga, pembelajaran reflektif dapat menguatkan motivasi; keempat pembelajaran reflektif membantu pembentukan pribadi; kelima, pembelajaran reflektif tidak berdampak jika terlalu sering digunakan.

Grafik 4: Dampak Pembelajaran Reflektif

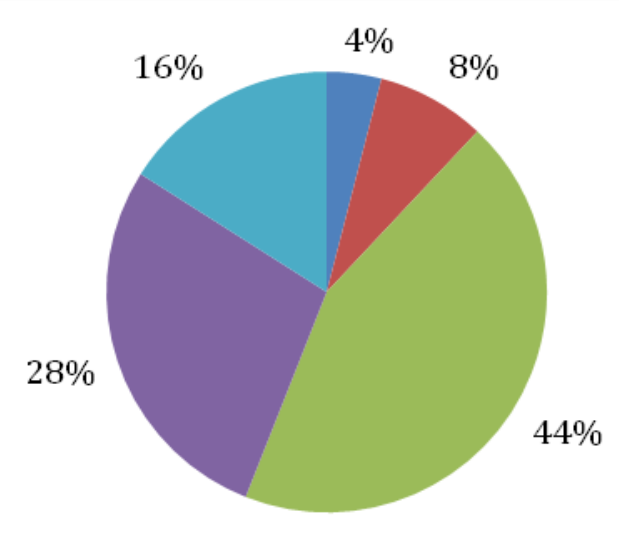

- Mengetahui tugas guru

Menyiapkan diri

Menguatkan motivasi

- Pembentukan pribadi

- terlalu sering kurang berdampak 
Dari 5 jenis jawaban responden, terdapat 3 jenis jawaban yang sangat dominan yaitu bahwa pembelajaran reflektif menguatkan motivasi, membantu dalam pembentukan diri dan jika terlalu sering kurang berdampak. Pertama pembelajaran reflektif menguatkan motivasi. Para responden menyadari bahwa melalui kegiatan refleksi atas berakhirnya proses kegiatan/perkuliahan membantu mereka untuk dapat memaknai kegiatan. Melalui kegiatan pemaknaan tersebut mereka mendapatkan pegangan hidup untuk melanjutkan tugas dan menyiapkan diri bagi tanggung jawab yang akan mereka emban di masa depan. Melalui kegiatan refleksi mereka juga dapat membangun niat untuk memperbaiki diri dan sikap.

Kedua pembelajaran reflektif membantu dalam pembentukan diri. Para responden menyadari bahwa menjadi guru tidak hanya mengajar dengan kata-kata namun juga sikap, tingkah laku dan perbuatan. Dengan kata lain menjadi guru berarti memberi teladan hidup. Agar dapat menjadi teladan hidup tidak cukup hanya pandai berkata-kata tetapi juga harus menunjukkan dalam tingkah laku sehari-hari. Apalagi menjadi guru juga dituntut harus siap melayani para peserta didik. Situasi ini membuat para responden menyadari bahwa agar menjadi pribadi yang unggul dan bijaksana dibutuhkan kemampuan mengevaluasi diri. Salah satu cara mengevaluasi diri yang dapat dilakukan adalah dengan refleksi. Melalui refleksi, mereka dapat menemukan kelebihan dan kekurangan yang ada dalam diri masing-masing untuk nantinya diperbaiki.

Ketiga, pembelajaran reflektif jika terlalu sering akan kurang berdampak. Para responden rupanya melihat dampak negatif dari pembelajaran reflektif. Salah satu dampak yang dirasakan adalah ketika kegiatan refleksi dilakukan secara berulang-ulang dan demi nilai rupanya kurang berdampak. Bagi para responden, refleksi yang dilakukan secara berulang-ulang dan demi nilai pada akhirnya akan jatuh pada upaya mencari nilai. Dimana saat berefleksi mereka hanya menuliskan hal-hal yang baik agar dosen merasa senang, namun rupanya dalam kehidupan riil hal tersebut kurang diwujudkan. Berdasarkan situasi tersebut, pembelajaran refleksi yang memiliki tujuan baik pada akhirnya tidak berdampak karena bertujuan untuk mencari nilai bukan memaknai pengalaman dan memperbaiki diri.

Dengan demikian, berdasarkan hasil penelitian dapat disimpulkan bahwa pembelajaran reflektif sangat berdampak bagi perkembangan kepribadian para calon guru. Dampak positif yang paling dirasakan oleh para responden bahwa pembelajaran reflektif ini membantu mereka dalam memotivasi diri dan pembentukan pribadi. 


\subsection{Pengaruh Pembelajaran Reflektif dalam Memotivasi Sebagai Calon Guru}

Hasil penelitian menunjukkan bahwa pembelajaran reflektif memiliki dampak yang besar dalam memotivasi panggilan menjadi guru. Hal ini dapat dilihat dari persentase jawaban responden, ketika memberi penilaian antara skala 1-5 terhadap pembelajaran reflektif.

Pada umumnya responden memberi penilaian 4 atau 5 terhadap besarnya pengaruh pembelajaran reflektif dalam memotivasi panggilan. Dari data terlihat bahwa 43\% responden memberi penilaian 4 (besar). Selanjutnya terdapat 29\% responden memberi penilaian 5 (sangat besar).

Grafik 5: Pengaruh Pembelajaran Reflektif

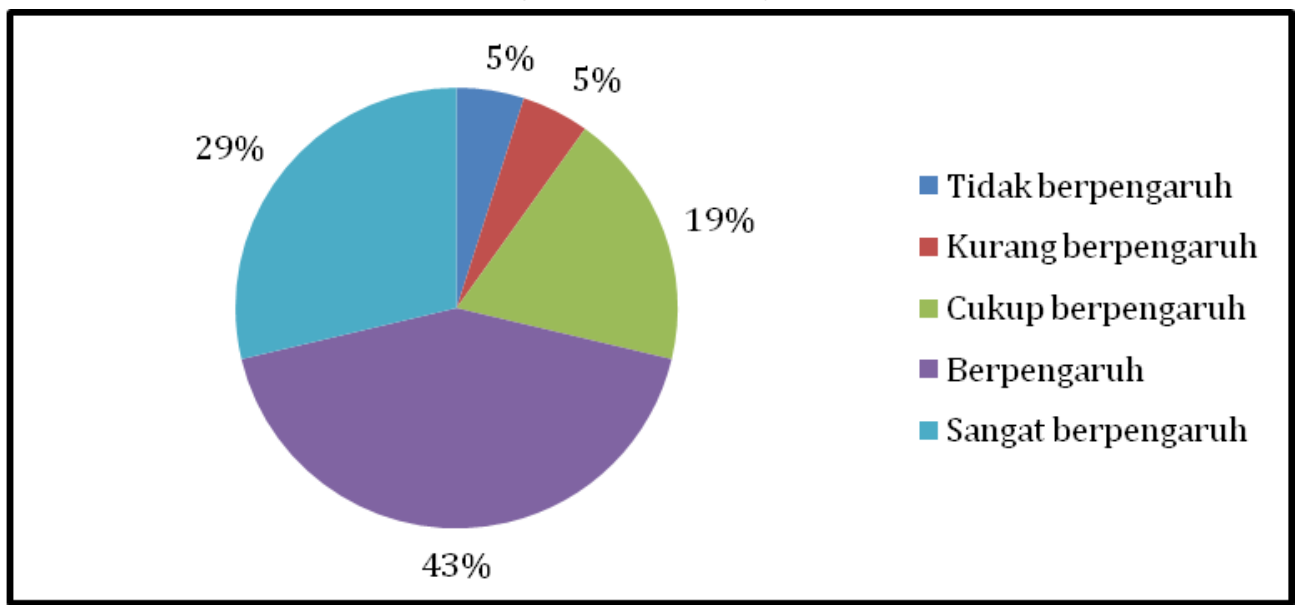

Penilaian yang diberikan para responden tentu tidak lepas dari pengalaman yang mereka sampaikan. Para responden merasa bahwa melalui pembelajaran reflektif motivasi mereka untuk menjadi guru semakin dimurnikan. Mereka juga merasa bahwa pembelajaran reflektif membantu mereka dalam menyiapkan diri agar dapat menjadi guru yang unggul.

\section{KESIMPULAN}

Berdasarkan hasil penelitian tentang Dampak Pembelajaran Reflektif Bagi Calon Guru Agama Katolik Terhadap Panggilan Keguruan dapat disimpulkan beberapa hal, yaitu:

a. Pembelajaran reflektif dapat membantu peserta didik dalam memaknai proses pembelajaran dan menemukan kontekstualisasi materi.

b. Pembelajaran reflektif memiliki keunggulan yaitu membantu peserta didik untuk mampu mengkontektualisasikan materi, memahami materi yang diajarkan, memperbaiki diri dan memaknai pengalaman hidup. 
c. Pembelajaran reflektif juga memiliki kelemahan terutama jika pembelajaran reflektif digunakan sebagai sarana penilaian hasil belajar. Apabila pembelajaran reflektif digunakan sebagai penilaian peserta didik ada kemungkinan akan berorientasi pada nilai sehingga ada kemungkinan membuat mereka berbohong atas proses refleksi yang dilakukan.

d. Pembelajaran reflektif memberi dampak sangat besar dalam memotivasi panggilan sebagai guru dan membantu dalam membentuk kepribadian para calon guru.

e. Berdasarkan berbagai kesimpulan tersebut maka hendaknya pembelajaran reflektif dimanfaatkan dalam perkuliahan dalam rangka membantu peserta didik untuk semakin memahami materi perkuliahan dan pada akhirnya mampu menemukan kontekstualisasi materi yang diperoleh. Selain itu pula, pembelajaran refleksi membantu para peserta didik untuk semakin termotivasi menjadi guru. 


\section{DAFTAR PUSTAKA}

Hartana, Albertus, Punaji Setyosari \& Dedi Kuswandi. 2016. Penerapan Strategi Pembelajaran Paradigma Pedagogi Ignatian (Reflektif) terhadap Peningkatan Hasil Belajar dan Motivasi Berprestasi Belajar Ilmu Pengetahuan Alam (IPA) siswa Kelas V Sekolah Dasar. Jurnal Pendidikan: Teori, Penelitian, dan Pengembangan, 1(4), 765-779.

Marnita. 2017. Model Pembelajaran Reflektif Learning untuk Meningkatkan keterampilan Proses Sains dan Penguasaan Konsep Siswa Pokok Bahasan Kalor dan Perpindahannya di Kelas VII MTSN. Jurnal Pendidikan Almuslimin, 5(1), 23-29.

Putra, Fredi Ganda. 2016. Pengaruh Model Pembelajaran Reflektif dengan Pendekatan Matematika Realistik Bernuansa Keislaman terhadap Kemampuan Komunikasi Matematis. Al-Jabar: Jurnal Pendidikan Matematika, 7(2), 203-210.

Putri, Stefani Dwiana, Veronika Ines Nugraheni, Hanik Sri Pratini. 2016. Analisis Hasil Refleksi Dalam Penerapan Pendekatan Paradigma Pedagogi Reflektif Pada Pembelajaran Matematika di Kelas X6 SMA Kolose De Brito Yogyakarta. Prosiding Seminar Nasional Matematika dan Terapannya, 297-305.

Saptono. 2012. Pembelajaran Reflektif: Upaya Membumikan Hermeneutik dalam Praktik Pendidikan. Satya Widya, 28(1), 73-82.

Subagya, Y. 2010. Paradigma Pedagogi Reflektif Mendampingi Peserta didik Menjadi cerdas dan Berkarakter. Yogyakarta: Kanisius.

Suparno, Paul. 2015. Pembelajaran di Perguruan Tinggi Bergaya Paradigma Pedagogi Refleksi (PPR). Yogyakarta: Kanisius.

Wahana, Paulus. 2018. Mengenal Pendekatan Paradigma Pedagogi Reflektif dalam Pendidikan untuk Membangun Manusia yang Cerdas dan Humanis. Didaktika.

Diakses https://journal.uny.ac.id/index.php/didaktika/article/.../8536. pada 1 Oktober 2018.

Wahyuni, Sri. 2014. Profesi Guru Adalah Panggilan Ilahi. Jurnal Antusias, 3(5), 147-160.

(http://www.sttintheos.ac.id/ejournal/index.php/antusias/article/view/18). 